THE KURUME MEDICAL JOURNAL

1976 Vol. 23, No.3, p. 139-143

\title{
EPON-FREEZE CRACKING FOR SCANNING ELECTRON MICROSCOPY
}

\author{
TATSUO SHIMADA, KATSUTOSHI OTA ${ }^{1)}$, MASATOSHI YAMAMOTO \\ AND MASAHIRO MURAKAMI
}
Second Department of Anatomy and Third Department of Internal Medicine ${ }^{1)}$, Kurume University School of Medicine, Kurume, 830, Japan

(Received for publication August 27, 1976)

\begin{abstract}
Freeze cracking was carried out to visualize intracellular structures with scanning electron microscope (SEM). Tissues embedded in Epon 812 without any catalyst were frozen in liquid nitrogen and cracked at room temperature. After removal of the epoxy resin by displacing with propylene oxide, specimens were dried by critical point drying method. Then, the cracked face was ion-etched prior to coating with gold. The cracking technique was very easy, and the well-preserved structures of some organelles were demonstrated on the fractured faces thus obtained.
\end{abstract}

\section{INTRODUCTION}

Recently, several reports have been published as to the methods which use epoxy resin as an embedding medium for SEM. Tanaka (1972) invented a "frozen resin cracking method" utilizing cemedine 1500, while Humphreys et al. (1973) proposed a method to freeze-crack the tissues embeded in plastic. The cracked surfaces exposed by these methods revealed well preserved figures of intracellular organelles, but the methods are a little complicated in procedure. In other methods, Araldite-embedded sections $(1-50 \mu)$ cut with an ultramicrotome were etched chemically with sodium hydroxide or sodium methoxide, and viewed by SEM (Thurley et al., 1974; Judge and Stubb, 1975). However, it seems that the latter method is somewhat questionable in explaining the sequential structural detail.
For these reasons, we have devised a simple freeze-cracking method by using Epon 812 (Luft, 1961) which is most familiar to microanatomists in making the preparations for transmission electron microscope (TEM). Since excellent preservation of the fine structures within the cell was possible, the detailed technical managements of the method and the results obtained from some tissues are described in this paper.

\section{MATERIALS AND METHODS}

The materials used are the pancreatic tissues of adult Japanese monkeys and the cardiac muscle of the left ventricle of adult rats. The procedures are as follows.

1. Pieces of the tissues are fixed in $2.5 \%$ glutaraldehyde buffered with cacodylate and 1-2\% osmium tetroxide.

2. They are dehydrated with grade 
series of aceton and then are treated with propylene oxide for $30 \mathrm{~min}$.

3. Specimens are immersed in Epon 812 without catalyst for more than 3 hrs. and embedded in small gelatin capsules (No. 4 or 5) filled only with Epon 812.

4. Embedded specimens are frozen in a beaker filled with liquid nitrogen, taken out of the beaker, and cracked with a knife and hammer at room temperature.

5. The resin is removed from the tissue by immersing in propylene oxide for $2 \mathrm{hrs}$., the solvent being changed several times.

6. After removal of the resin, propylene oxide is further replaced with isoamyl acetate.

7. Specimens are dried by critical point drying method using liquid carben dioxide (Anderson, 1951).

8. The cracked surface of the tissue is ion-etched (AC. $500 \mathrm{~V}, 10-15 \mathrm{~min}$ ) in the ion bombardment apparatus (EicoIB - I) in order to reveal more distinctly the three-dimensional structure (Akahori and Fukuoka, 1975), and then coated with gold in the same apparatus.

9. The samples are examined under SEM (HFS- II ).

\section{RESULTS}

Fig. 1 shows the fractured surface of the pancreatic acinar cells. The nuclei are central to basal in position and rounded in shape, in which large nucleoli are prominent. The basal half of the cell is mostly filled with tubules of the granular endoplasmic reticulum and a few mitochondria. The apical half contains a number of round, membranebounded granules, so-called zymogen granules. Some granules show flat fractured surface, and others present protrusions of the surface. Higher magnification of the apical part indi- cates that some of them are found to be in the stage at which their content is just now discharging into the lumen of the acinus. The free surface of the acinar cells bears a few short microvilli (Fig. 2).

Figs. 3 and 4 are SEM images showing a longitudial section of the cardiac muscular fiber. From these pictures, it is possible to identify the A, I, and $\mathrm{Z}$ bands. Further, the $\mathrm{H}$ band and the $M$ line are seen clearly. In Fig. 3, nucleus shows a plateau-like profile since the cracking might occur along the nuclear membrane. On its surface, numerous nuclear pores can be found. In the sarcoplasm, large mitochondria with densely packed cristae and tubules of the smooth endoplasmic reticulum are observed between myofibrils.

\section{COMMENTS}

The new freeze-cracking method using Epon 812 which has been really available for preparing the specimens for TEM since Luft's report (1961) has some significant characteristics.

From the viewpoint of freeze-cracking technique, our method does not require such special instruments as cryostat and refrigerator for hardening resin (Tanaka, 1972), and specimens embedded in Epon 812 can be frozen up in a beaker filled with liquid nitrogen. Even small specimens and muscle fibers can be easily cracked with a knife and hammer. In brief, the present method is quite simple.

Freeze-fracture has been applied to SEM by some investigators (Germinario and McAlear, 1971; Brooks and Haggis, 1973). In these methods, the structures of cell surface were well preserved, but the cut surface of cells often revealed severe damage by ice crystallization. In our method, such type of damage does not occur on the cracked surface 
at all. The cracked surface reveal that the structures including nuclei, organelles and other components are well preserved just as shown in figures I - IV. Further, it is found that ionetching on the cracked surface is very effective in reconstructing three-dimensionally their fine architecture.

In conclusion, it appears that the cracking method described here is extremely practical in preparing the specimens for the SEM in order to visualize the intracellular structures.

\section{REFERENCES}

Akahori, H. and Fukuoka, T. (1975). Development and application examples of ion bombardment apparatus. J. Electron Microscopy, 24, 49-51.

ANDERson, T. F. (1951). Techniques for preservation of three-dimensional structure in preparing specimens for the electron microscope. Trans, N.Y. Acad. Sci., 13, 130-134.

BRooks, E. E. H. and HAGGIS, C. H. (1973). Scanning electron microscopy of rat's liver. Application of freez-fracture and freezedrying techniques. Lab. Invest., 29, 60-64.

Germinario, L. T. and Mcalear, J. H. (1971). Preparation of tissue for scanning electron microscopy ; Freeze fracturing as a technique for enhancing visibility of structural relationships. Stain Technol, 46, 249-252.

HumphreYs, W.J., WODYiCKI, T.J. and RAUliN, J. J. (1973). Fractographic studies of plasticembedded cells by scanning electron micro- scopy. J. Cell Biol, 56, 876.

JUDGE, F. J. and STUbBS, J. M. (1975). Scanning electron microscopy of tissue preparations after removal of epoxy resin. Stain Technol, 50, 133-134.

LuFT, J. H. (1961). Improvements in epoxy resin embeddeing methods. J. biophys. biochem. Cytol, 9, 409.

TANAKA, K. (1972). Frozen resin cracking method for scanning electron microscopy of biological materials. Naturwissenchaften, 59, 77.

Thurley, K. W. and Mouel, W. (1974). The etching of thick Araldite-embedded sections for scanning electron microscopy. J. Microscopy, 101, 215-218.

\section{EXPLANATION OF FIGURES}

Fig. 1 Fractograph of the pancreatic acinar cells of the monkey. The nucleus $(\mathrm{N})$ with prominent nucleoli, organelles including the rough endoplasmic reticulum, and zymogen granules $(Z G)$ are distinctly observable. $\mathrm{L}$, lumen $(\times 6,000)$.

Fig. 2 Higher magnification of the apical part of the acinar cells. MV, microvilli, ZG, zymogen granule $(\times 23,000)$.

Fig. 3 Fractograph of the cardiac muscle fiber of the rat. A, I and $\mathrm{Z}$ bands are clearly recognized. Note nuclear pores on the nucleus $(\mathrm{N}) . \mathrm{M}$, mitochondrion $(\times 14,000)$.

Fig. 4 Higher magnification of the cardiac muscle fiber. Between myofibrils are the prominent mitochondria (M) with well developed cristae. $Z, Z$ band $(\times 28,000)$. 

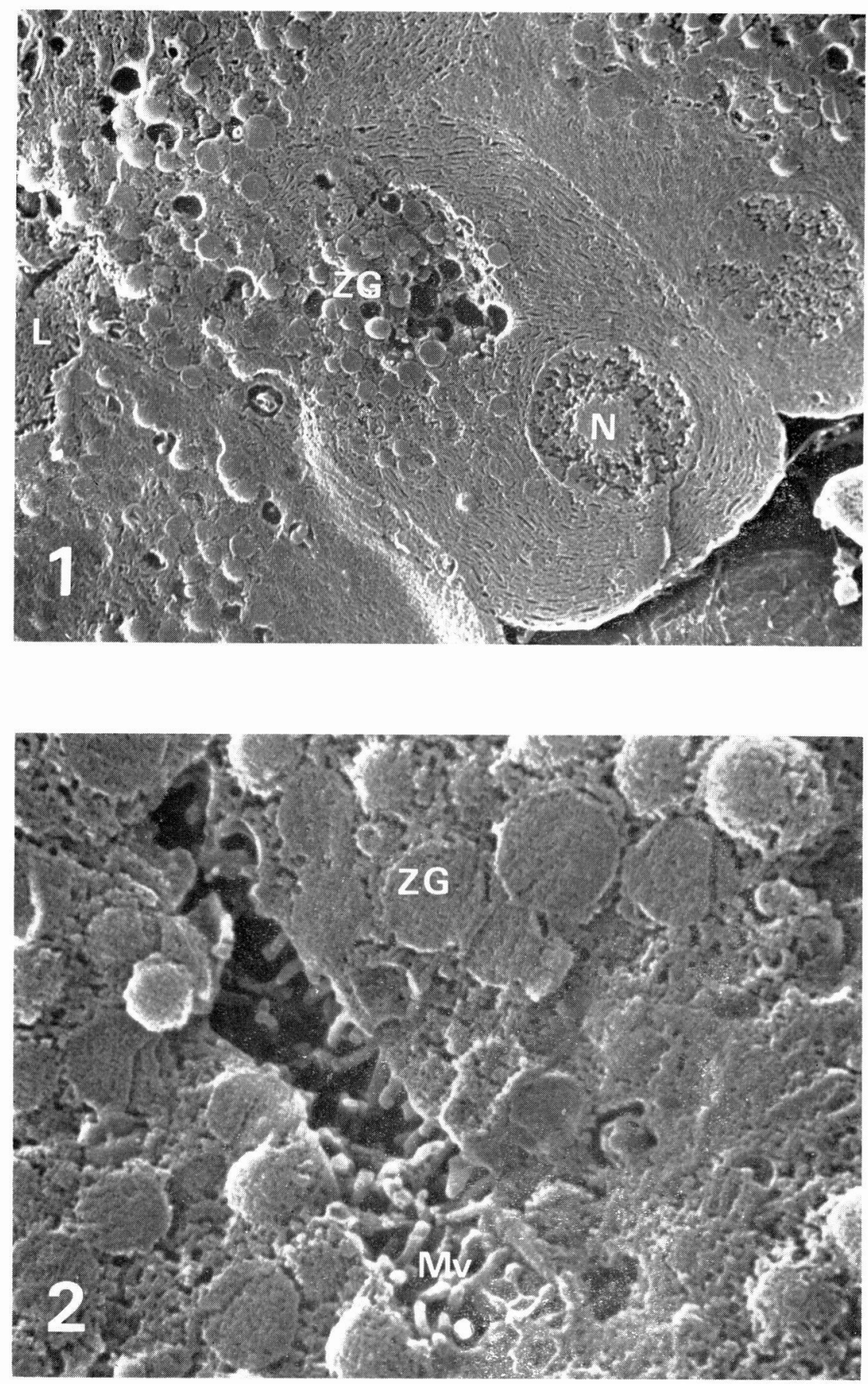

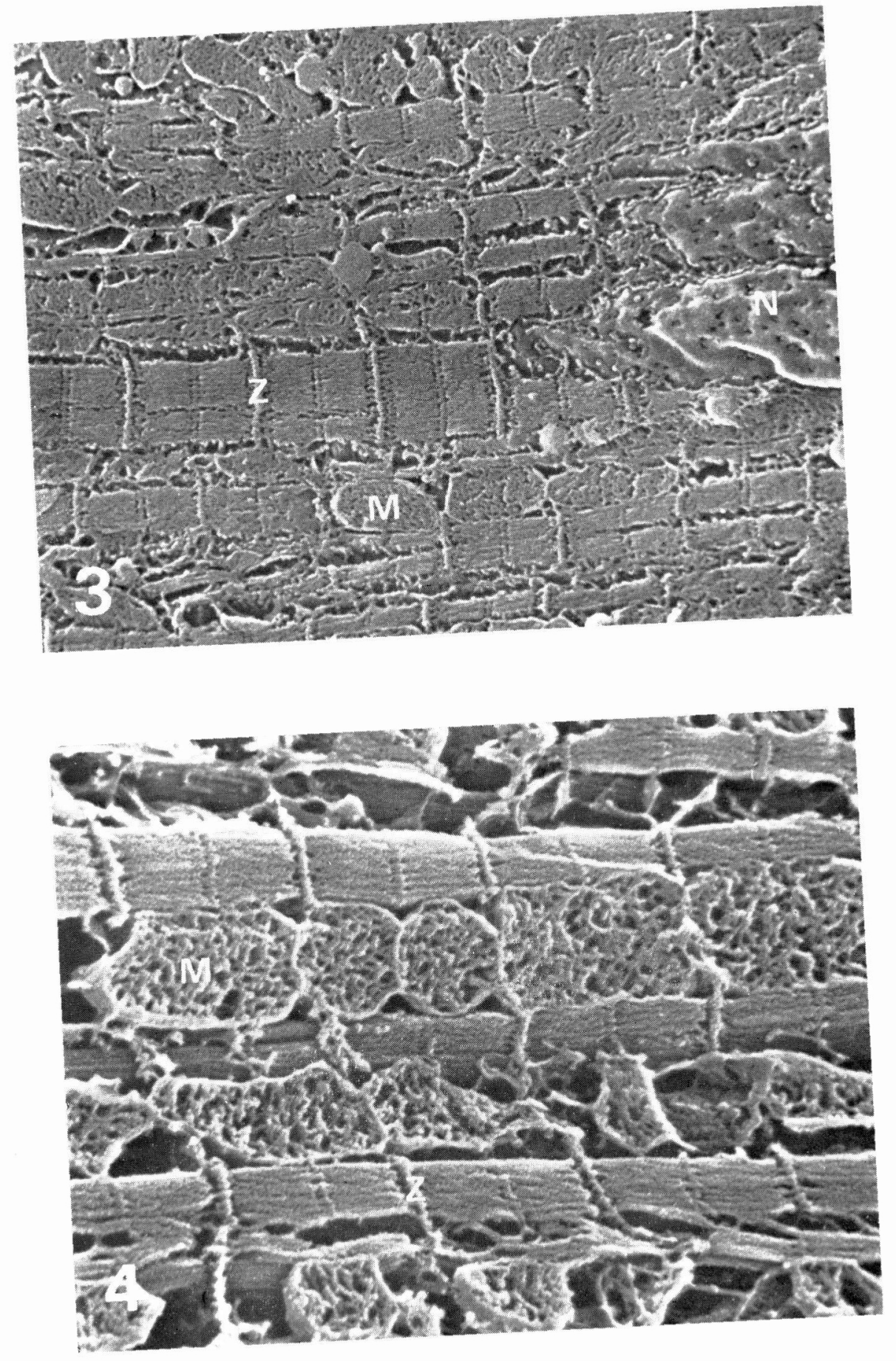